Edutech, Tahun 13, Vol.1, No.1, Februari 2014

\title{
HUBUNGAN PELAJAR SMA DENGAN GURU DI KOTAMADYA BANDUNG
}

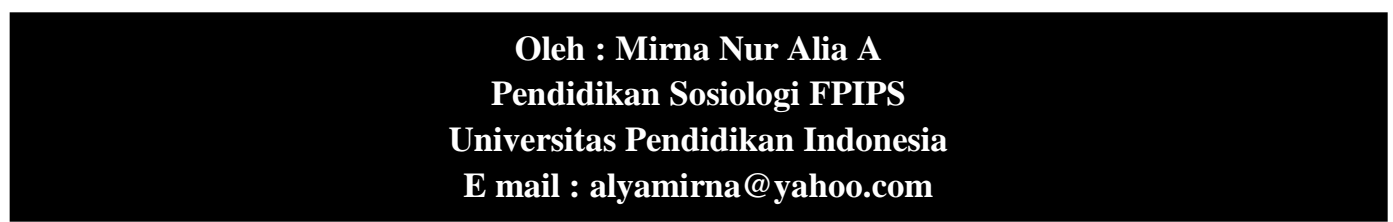

Abstract, this article analyses relationship between students of senior high school (SMA)and their teachers in terms of learning process in Bandung. According to students perception, they have many problems in relation with their teachers, such as communication gap, conflicts and difficult to understand what the teachers say in classes. However, those students have some efforts to solve those problems. The objective of this study is to seek how youth overcome their problems in order to challenge their future.

Key Word: Relations, Teacher, Student

Abstrak, artikel ini menganalisis tentang hubungan antara pelajar SMA dan guru mereka dalam proses kegiatan belajar mengajar di Bandung. Berdasarkan persepsi pelajar, mereka memiliki banyak kendala dalam menghadapi hubungan dengan para guru, seperti kesenjangan komunikasi, konflik-konflik, dan kesulitan untuk memahami apa yang guru sampaikan di kelas. Namun, sebagai pelajar, mereka tetap memiliki usaha dan keinginan untuk menyelesaikan masalah tersebut. Tujuan dari kajian ini adalah untuk mencari bagaimana remaja mengatasi masalah mereka dalam rangka untuk menantang masa depan mereka.

Kata Kunci : Hubungan, Guru, Siswa

\section{A. PENDAHULUAN}

Sumber daya manusia Indonesia berkualitas merupakan kekuatan efektif untuk mempercepat proses pembangunan nasional menuju ke arah tercapainya tujuan nasional. Salah satu lapisan penduduk yang potensial menjadi sumber daya manusia adalah pelajar sekolah menengah atas (SMA). Pelajar SMA adalah mereka yang pada umumnya berumur antara 15-19 tahun. Dari rentangan umur mereka termasuk dalam lapisan kelompok orang muda (youth), yaitu yang berumur antara 15-24 tahun (UNESCO, 1983).

Banyak pertimbangan yang dapat dikemukakan melalui suatu penelitian terhadap potensi pelajar SMA sebagai generasi penerus. Melihat data statistik jumlah penduduk yang berusia 15-19 tahun di Jawa Barat adalah 3.761.418 orang atau $11 \%$ lebih dari jumlah penduduk Jawa Barat keseluruhan. Sedangkan jumlah pelajar di kota Bandung SMA 18.544 dan SMK 19.631 (Biro Pusat Statistik Jabar, 2011). 
Edutech, Tahun 13, Vol.1, No.1, Februari 2014

Untuk dapat menentukan suatu situasi stimulus bersama dengan isi ingatan kebijaksanaan jangka pendek maupun mempengaruhi siswa sedemikian rupa jangka panjang (PJPT II), perlu diketahui sehingga perbuatannya berubah (respons) lebih dulu apa, siapa dan bagaimana profil pelajar SMA (secara umum orang muda) dengan melihat persoalan-persoalan yang mereka hadapi. Tulisan kajian ini memfokuskan pada: Profil pelajar SMA dilihat dari persoalan-persoalan yang mereka hadapi dengan sekolah dalam hal ini guru, yang berkaitan erat dengan mata pelajaran yang diajarkannya, serta penyebab dari persoalan-persoalan tersebut dan upaya apa yang dilakukan untuk mengatasi persoalan tersebut.

Dalam melihat profil pelajar SMA di Kotamadya Bandung dari sudut pandang persoalan yang mereka hadapi, penyebab dan upaya mereka mengatasinya, tulisan ini secara khusus akan membahasnya hubungan atau komunikasi antara murid dengan guru dalam proses belajar mengajar, beserta hambatan-hambatan apa yang terdapat di dalamnya.

\section{Tinjauan Pustaka}

Salah satu teori untuk membahas masalah hubungan pelajar dengan guru di kotamadya Bandung dapat menggunakan teori dengan model S-R (stimulusrespons). Gagne dalam buku the Conditions of Learning menyatakan: “ Belajar terjadi apabila suatu dari waktu ke waktu sesudah ia mengalami situasi tadi”.

Menurut Good and Brophy (1977) yang dimaksud belajar bukanlah tingkah laku yang tampak tetapi terutama adalah proses yang terjadi secara internal di dalam diri individu dalam usahanya memperoleh hubungan-hubungan baru. Hubunganhubungan baru itu dapat berupa: antara perangsang dengan perangsang, antara reaksi dengan reaksi, atau perangsang dengan reaksi (S-R). Clark C. Hull (dalam Purwanto 1990:97) mengemukakan teori belajar mengajar, yaitu "adalah suatu kebutuhan atas keadaan terdorong oleh motif, tujuan, maksud, aspirasi, ambisi harus ada dalam diri seseorang yang belajar sebelum suatu respons dapat diperkuat atas dasar pengurangan kebutuhan itu". Dalam hal ini efisiensi belajar bergantung pada besarnya tingkat pengurangan dan kepuasan motif yang menyebabkan timbulnya usaha belajar itu dan oleh respos-respons yang dibuat individu itu. Setiap obyek, kejadian atau situasi dapat mempunyai nilai sebagai penguat apabila hal itu dihubungkan dengan penurunan terhadap suatu keadaan deprevasi (kekurangan) pada diri individu 
Edutech, Tahun 13, Vol.1, No.1, Februari 2014

itu, yaitu apabila obyek, kejadian atau situasi tadi dapat menjawab suatu kebutuhan pada saat individu itu melakukan respons.

Prinsip penguat (reinforce) menggunakan seluruh situasi yang memotivasi, mulai dari dorongan biologis, yang merupakan kebutuhan utama seseorang sampai pada hasil-hasil yang memberikan ganjaran bagi seseorang (misalnya uang, perhatian, afeksi, dan aspirasi sosial). Jadi prinsip yang utama adalah suatu kebutuhan atau motif harus ada pada seseorang sebelum belajar itu terjadi, dan apa yang dipelajari itu harus diamati oleh orang yang belajar sebgai suatu yang dapat mengurangi kekuatan kebutuhannya. Dua hal yang sangat penting dalam proses belajar-mengajar dari Hull adalah adanya motivasi insentif (incentive motivation) dan pengurangan stimulus (drive stimulus reduction) (Purwanto, 1993).

Respons dikonfirmasi, yaitu respons yang merusak hubungan interpersonal, ditandai dengan:

a. Respons sekilas: hanya sedikit yang diperhatikan/perhatian pada hal lain

b. Respons kosong: tidak menghiraukan atau "cuek" c. Respons yang tidak relevan: respons yg berbeda dari yang diharapkan

d. Respons interupsi (tidak puas): menolak atau membantah

e. Respons kontradiktif: menentang, tidak setuju, dst.

Berdasarkan kedua jenis respons tersebut, akan dinilai jawaban-jawaban responden mengenai persoalan-persoalan dalam proses belajar terhadap guru yang mengajar. Persoalan di sini berikut pula dengan penyebabnya, serta upaya mereka mengatasi persoalan tersebut. Hasil analisis ini akan memperlihatkan bagaimana hubungan guru dan pelajar yang sebenarnya.

Seperti telah dijelaskan di muka responden berjumlah 110 orang pelajar dari 5 SMA di Kodya Bandung. Mereka terdiri dari: 37 orang kelas $\mathrm{X}, 30$ orang kelas XI, dan 43 orang kelas XII, 61 orang laki-laki dan 49 orang perempuan.

Dari 110 orang responden tersebut, yang menyatakan mempunyai persoalan dengan guru sebanyak 58 orang $(63,8 \%)$ dan yang tidak mempunyai persoalan sebanyak 52 orang $(57,2 \%)$. Perlu dicatat bahwa persoalan yang dimaksud adalah persoalan dengan satu atau dua guru saja, bukan berarti dengan semua guru. Namun karena penelitian ini berfokus pada 
Edutech, Tahun 13, Vol.1, No.1, Februari 2014

persoalan dengan guru secara umumnya, maka analisis terhadap masing-masing guru tidak dikemukakan atau diteliti.

Dari data tersebut dapat diinterpretasikan bahwa bagi yang tidak mempunyai persoalan dengan guru berarti hubungan mereka tidak terganggu dengan persoalan dan penyebab, bukan mereka tidak ada respons. Dengan perkataan lain mereka tidak mempunyai hambatan emosional dengan guru, sehingga hubungan mereka berjalan dengan lancar. Hal ini berpengaruh dalam proses belajar mengajar, di mana stimulus diberikan dan respons baik dan lancar. Sebaiknya bagi yang menyatakan "ada persoalan dengan guru", ini berarti hubungan terganggu oleh persoalan dan penyebabnya, di mana ada hambatan emosional dengan guru, mengakibatkan hubungan tidak lancar atau tidak baik. Jadi stimulus mendapat respons dikonfirmasi.

Pembahasan selanjutnya adalah melihat pelajar yang mempunyai persoalan dengan guru $(\mathrm{n}=58)$.

Tabel I

\begin{tabular}{|l|c|c|}
\hline \multicolumn{1}{|c|}{ Persoalan } & Jumlah & Presentase \\
\hline Sulit berkomunikasi & 35 & $60,34 \%$ \\
\hline Konflik & 17 & $29,32 \%$ \\
\hline Lainnya & 6 & $10,34 \%$ \\
\hline Total & 58 & $100 \%$ \\
\hline
\end{tabular}

Kategori Persoalan dengan Guru

$$
\mathrm{n}=58
$$

Sumber : Hasil Survei 2013

\section{Metodologi}

Penelitian ini bersifat eksploratif. Data yang dikumpulkan dari penelitian ini adalah data primer dan sekunder yang bersifat kuantitatif dan kualitatif. Data primer diperoleh dengan metode survei dengan teknik wawancara berstruktur, yaitu wawancara terhadap responden secara mendalam dengan berpedoman pada daftar pertanyaan. Data sekunder diperoleh melalui instansi terkait.

Penarikan sampel dilakukan dengan multi-stage yang terdiri dari tiga tahap. Pertama menentukan empat SMA dari SMA yang ada di Kotamadya Bandung dengan random sampel sederhana (diundi). 
Edutech, Tahun 13, Vol.1, No.1, Februari 2014

Kedua, menentukan jumlah responden dari masing-masing sekolah menurut jumlah murid keseluruhan di sekolah-sekolah itu. Ketiga menetapkan responden dengan teknik systematic random sampling. Kemudian dari metode tersebut diperoleh 110 responden masing-masing:

a. SMA Negeri 8, 37 orang responden

b. SMA Negeri 3, 20 orang responden

c. SMA Negeri 1, 20 orang responden

d. SMA Negeri 20, 33 orang responden

Metode analisis adalah deskripsi hubungan stimulus-respons dimana stimulus adalah guru dengan suatu mata pelajaran yang diberikan respons dari pelajar (murid). Di sini peranan guru dilihat dari sikap dan kepribadian guru, cara mengajar, tinggi rendahnya pengetahuan yang dimiliki guru, dan bagaimana cara mengajar pengetahuan itu kepada anak-anak didik. Di lain pihak respons itu adalah persoalan yang dihadapi pelajar berkenaan dari stimulus yang diberikan guru serta penyebabnya.

Perlu dijelaskan bahwa data diambil dari pelajar saja, belum dari pihak guru yang sebagai pihak yang memberikan stimulus, karena belum terprogram, memang kelemahan dari analisis ini hanya melihat bagaimana melihat respons dari pelajar yang akan dilihat profil pelajar itu secara keseluruhan, karena fokus penelitian besar (seluruh Indonesia) adalah orang muda (pelajar) yang dikaitkan dengan masa depan, profil mereka sebagai generasi penerus. Oleh karena itu dilihat pula bagaimana mereka mengatasi persoalan dan penyebabnya dengan upayaupaya yang dilakukan.

Analisis mengenai "hubungan" adalah hubungan interpersonal antara guru dengan pelajar. Gambaran dari hubungan interpersonal ini adalah "baik" dan "tidak baik", dilihat dari respons. Tubb dan Moss (1974) membagi respons dalam dua kelompok yaitu:

1. Respons konfirmasi : yaitu respons yang akan memperteguh hubungan interpersonal ini ditandai dengan :

a. Penerimaan/pengakuan langsung: suka, setuju

b. Perasaan positif: suka, setuju

c. Respons bertanya atau minta keterangan: ingin lebih tahu, berminat

d. Respons setuju: mendukung karena sudah tahu/mengerti

e. Respons dukungan

Untuk mengetahui "penyebab' dari persoalan-persoalan tersebut kita lihat tabel berikut ini. 


\section{Tabel II}

\section{Penyebab dan Persoalan dengan Guru}

$$
\mathbf{n}=\mathbf{5 8}
$$

\begin{tabular}{|l|c|c|c|c|}
\hline \multicolumn{1}{|c|}{1} & 2 & 3 & 4 & 5 \\
\hline Segan/takut & $13(22,4 \%)$ & $1(1,7 \%)$ & - & $14(24,1 \%)$ \\
\hline Guru otoriter & $8(13,7 \%)$ & $13(22,4 \%)$ & - & $19(32,7 \%)$ \\
\hline $\begin{array}{l}\text { Guru tidak } \\
\text { responsive }\end{array}$ & $11(18,9 \%)$ & $1(1,7 \%)$ & - & $12(20,6 \%)$ \\
\hline Guru pilih kasih & $2(3,44 \%)$ & $3(5,1 \%)$ & - & $5(8,6 \%)$ \\
\hline $\begin{array}{l}\text { Guru sering } \\
\text { absen }\end{array}$ & $1(1,7 \%)$ & - & - & $1(1,7 \%)$ \\
\hline Lainnya & - & $1(1,7 \%)$ & $5(7 \%)$ & $7(12,3 \%)$ \\
\hline Total & $35(60,3 \%)$ & $19(32,7 \%)$ & $5(7 \%)$ & $58(100 \%)$ \\
\hline
\end{tabular}

Sumber : Hasil survei 2013

Keterangan:

$1=$ Penyebab persoalan

$2=$ Persoalan Sulit Berkomunikasi

$3=$ Persoalan konflik

4 = Lainnya

$5=$ Jumlah

Pernyataan segan/takut, guru bicara masalah di luar pelajaran. Di luar otoriter, dan guru tidak responsif, kelas ada sikap acuh tak acuh pada guru merupakan jumlah yang terbanyak. Dari (karena segan/takut, menganggap guru wawancara mendalam alasan mereka, otoriter dsb). Hal ini memperlihatkan karena guru bersikap "kaku", hubungan memang ada "jarak" anatara murid dan yang terjadi hanya dalam kelas pada proses guru, sehingga sulit berkomunikasi.

belajar mengajar, di luar kelas guru seperti Persoalan konflik diartikan sebagai tidak mengenal murid, dan tidak berusaha "ada gap" yang cukup jauh antara murid mendekat, misalnya dengan bertanya, atau dan guru, dan terungkap ada perasaan 26 Hubungan Pelajar SMA Dengan Guru Di Kotamadya Bandung 
Edutech, Tahun 13, Vol.1, No.1, Februari 2014

"tidak suka". Sehingga bukan hanya sulit berkomunikasi, tapi cenderung menghindari berhubungan dengan guru.

Penyebab lainnya dinyatakan dengan : "guru mudah tersinggung, ketika diajak bercanda, sehingga marah dan menantang berkelahi”. Selain itu yang diungkapkan dengan spontan 5 (7\%) yaitu "tidak semangat untuk belajar", "kecewa terhadap guru", "guru bicara/mengajar terlalu cepat", sehingga sulit dimengerti.

Seperti telah dikemukakan, analisis hubungan pelajar SMA dengan guru dinyatakan dengan "baik" dan "tidak baik" dimana menurut teori hubungan interpersonal dapat diukur dengan respons konfirmasi berarti akan memperteguh hubungan interpersonal (baik), dan respons dikonfirmasi yang berarti akan rusaknya hubungan tersebut (tidak baik). Dari persoalan "sulit berkomunikasi" dan "konflik" terlihat respons dikonfirmasi dari pelajar secara jelas diungkapkan oleh mereka dalam bentuk penyebab-penyebab persoalan yang telah dikemukakan. Sehingga respons menjadi acuh tak acuh, diam (karena segan/takut), karena menganggap guru otoriter, tidak responsif dan pilih kasih, disebut dengan responssekilas dan kosong. Hal ini menyebabkan interaksi sehari-hari tidak ada keserasian, hubungan yang "dingin" antara pelajar yang mempunyai persoalan dengan guru. Padahal dalam proses belajar mengajar hal ini tidak boleh terjadi.

Aminudin Rasyad (1990) dalam membahas mengenai sikap guru mengemukakan bahwa suatu kecenderungan jiwa atau batiniah seseorang yang selalu dalam keadaan siap bereaksi dalam bentuk tingkah laku yang kelihatan terhadap perangsang yang datang kepadanya. Sikap ini dapat terbentuk dalam diri seseorang terutama guru, karena berdasarkan serangkaian pengalamannya berinteraksi dengan lingkungan pendidikan, lingkungan sosial sekitarnya. Makin banyak pengalaman seseorang dalam suatu masalah, makin terbentuk sikap dalam dirinya. Murid-murid akan menyenanginya. Ia akan selalu siap sedia menolong murid-murid yang membutuhkan pertolongannya. Sikap ilmiah akan tampak dalam penyajiannya, ia akan berusaha sedapat mungkin agar bidang studi yang disajikannya menjadi milik muridnya. Dia dapat membaca wajah muridnya yang merupakan pancaran jiwa, dan tanggap terhadap keadaan muridnya satu persatu.

Menurut S. Nasution (Aminuddin Rasyad, 1990), seorang guru akan disenangi muridnya apabila:
a. Membantu murid dalam proses belajar mengajar

b. Gembira dan memiliki rasa humor 
Edutech, Tahun 13, Vol.1, No.1, Februari 2014

c. Bersikap bersahabat, suka bergaul dengan muridnya

d. Adil, tidak mempunyai anak emas

e. Tegas dapat menguasai kelas/berwibawa

f. Dapat memberikan minat belajar murid dengan memberi motivasi Selanjutnya menjadi pertanyaan mengapa lebih dari $50 \%$ pelajar mempunyai persepsi bahwa mereka mempunyai persoalan dengan guru. Ada dua hal yang dapat diargumentasikan, pertama mungkin memang benar guruguru bersikap seperti yang dipersepsikan pelajar; kedua apakah karena karena keadaan jiwa pelajar yang dalam psikologi disebut suatu masa dengan serentetan penderitaan dan kegelisahan yang mereka harus hadapi. Keadaan ini menyebabkan mereka menghadapi masyarakat (termasuk guru, orang tua dan sebagainya) lebih banyak dengan sikap melawan (rejective) daripada sikap bersahabat (Soepartinah Parkasi, 1985). Masa ini disebut juga masa puber atau masa pancaroba, perubahan dari masa kanak-kanak ke masa dewasa, yang cenderung untuk mudah tersinggung, labil dan keras kepala, sehingga sering timbul perbedaan-perbedaan pendapat, konflik serta sulit berkomunikasi dengan orang lain.

Menghadapi pelajar yang mempunyai persoalan, guru seharusnya bersikap sebagai seseorang yang dihormati/disegani, tetapi juga harus dapat mendalami jiwa/sifat anak didik. Hal ini dalam hubungan antar manusia disebut empati, di mana guru dapat menghayati/merasakan apa yang sedang dirasakan oleh muridmurid, sehingga dapat memutuskan suatu kebijaksanaan tertentu dalam menjaga hubungan serasi dengan anak didik. Adalah salah sikap seorang guru yang diajak bercanda oleh murid, kemudian tersinggung dan menantang berkelahi, seperti yang diungkapkan salah seorang pelajar dalam penelitian ini. Kemudian ungkapan lain seperti segan dan takut, dari hasil wawancara mendalam, menurut pengakuan pelajar adalah karena guru "galak", kaku, otoriter, sehingga dalam proses belajar mengajar pelajar merasa tertekan dan terpaksa. Demikian pula ungkapan "guru tidak responsif", "pilih kasih", "sering absen", jika menerangkan pelajaran terlalu cepat dst, menyebabkan rasa kecewa yang terus menerus, tidak bersemangat belajar, kurang puas, dsb. Situasi yang demikian cenderung menggambarkan hubungan yang tidak harmonis antara guru dengan sebagian pelajar.

\section{B. HASIL DAN PEMBAHASAN}

Penelitian ini mengamati upaya apa yang dilakukan pelajar untuk mengatasi persoalan-persoalan mereka. Karena 
Edutech, Tahun 13, Vol.1, No.1, Februari 2014

penelitian besar (seluruh Indonesia) Berkaitan dengan persolan melihat profil pelajar (orang muda) dalam responden/pelajar dengan guru dan mengantisipasi masa depan mereka dan bagaimana upaya mengatasinya dapat ketangguhannya dalam menghadapi dilihat pada Tabel III persoalan-persoalan mereka.

Tabel III

Upaya dalam Mengatasi Persoalan

$\mathbf{n}=\mathbf{5 8}$

\begin{tabular}{|l|c|c|c|c|}
\hline \multicolumn{1}{|c|}{1} & 2 & 3 & 4 & 5 \\
\hline $\begin{array}{l}\text { Berdialog } \\
\text { dengan guru }\end{array}$ & - & $3(5,1 \%)$ & $1(1,7 \%)$ & $5(7 \%)$ \\
\hline $\begin{array}{l}\text { Meminta } \\
\text { bantuan orang } \\
\text { lain }\end{array}$ & $1(1,7 \%)$ & $8(13,7 \%)$ & $2(3,7 \%)$ & $14(24,1 \%)$ \\
\hline $\begin{array}{l}\text { Mengajukan } \\
\text { usul pada guru }\end{array}$ & $5(7 \%)$ & $1(1,7 \%)$ & - & $7(12,5 \%)$ \\
\hline $\begin{array}{l}\text { Menuruti } \\
\text { kehendak guru }\end{array}$ & $9(16,1 \%)$ & $7(12,5 \%)$ & $3(5,1 \%)$ & $19(32,7 \%)$ \\
\hline $\begin{array}{l}\text { Tidak ada } \\
\text { upaya }\end{array}$ & $2(3,44 \%)$ & $13(22,4 \%)$ & $2(3,44 \%)$ & $13(23,7 \%)$ \\
\hline Lainnya & $17(28,3 \%)$ & $35(57,1 \%)$ & $8(13,9 \%)$ & $58(100 \%)$ \\
\hline Total & & $1(1,7 \%)$ & - & - \\
\hline
\end{tabular}

Sumber: Hasil survei 2012

$$
\text { Keterangan: } \begin{array}{ll}
1=\text { Upaya } \\
2=\text { Persoalan Konflik } \\
3=\text { Persoalan Sulit Berkomunikasi } \\
4=\text { Lainnya } \\
5=\text { Jumlah }
\end{array}
$$

Tabel III ini memperlihatkan bahwa dalam berkomunikasi” sebagian besar mengatasi persoalan "konflik" dan "sulit menyatakan tidak ada upaya. Ini berarti 
Edutech, Tahun 13, Vol.1, No.1, Februari 2014

pasif, dan harus menjadi tanda tanya dan perhatian yang cermat. Karena persoalan mereka dengan guru akan berpengaruh dengan mata pelajaran yang harus diterima dari guru tersebut. Prestasi mereka diukur dari tingkat penguasaan terhadap pelajaran yang diterima, dan dapat dituangkan pada ulangan/tes dengan baik (masalah hasil tes/ulangan tidak diteliti).

Untuk lebih jelas masalah ini dapat diproyeksikan pada upaya pelajar dalam mengatasi persoalan dengan mata pelajaran.

Terlihat pada tabel IV hampir semua pelajar menyatakan mempunyai persoalan dengan mata pelajaran. Kategorisasi persoalan adalah sulit memahami, penyebabnya adalah karena hambatan pribadi seperti malas, pemahaman lemah, sikap guru tidak menyenangkan, cara guru mengajar tidak sistematis (wawasan kurang, kurang jelas, terlalu cepat, banyak rumus dan banyak hapalan). Kembali terlihat pada penyebab persoalan dengan mata pelajaran, muncul persoalan dengan guru, berarti ada kaitan erat antara guru dengan mata pelajaran.

Data ini memperlihatkan persoalan dengan guru dapat mempengaruhi penguasaan terhadap mata pelajaran, seperti timbul rasa malas, tetapi masalah dengan mata pelajaran belum tentu mempengaruhi hubungan dengan guru. Ini terbukti yang mempunyai persoalan dengan guru lebih sedikit $(51,4 \%)$ dari yang mempunyai persoalan dengan mata pelajaran $(94,4 \%)$.

Tabel IV

Upaya dan Persoalan dalam Mata Pelajaran

$\mathbf{n}=\mathbf{1 0 2}$

\begin{tabular}{|l|c|c|c|}
\hline \multicolumn{1}{|c|}{1} & 2 & 3 & 4 \\
\hline Belajar sendiri & $20(19,6 \%)$ & $7(6,9 \%)$ & $27(26,5 \%)$ \\
\hline $\begin{array}{l}\text { Belajar dengan } \\
\text { teman }\end{array}$ & $15(14,7 \%)$ & $10(9,8 \%)$ & $5(24,5 \%)$ \\
\hline $\begin{array}{l}\text { Bertanya kepada } \\
\text { orang lain }\end{array}$ & $5(4,9 \%)$ & $7(6,9 \%)$ & $12(11,8 \%)$ \\
\hline $\begin{array}{l}\text { Mengikuti } \\
\text { les/kursus }\end{array}$ & $15(14,7 \%)$ & $7(6,9 \%)$ & $22(21,6 \%)$ \\
\hline $\begin{array}{l}\text { Bertanya pada } \\
\text { guru }\end{array}$ & $2(1,9 \%)$ & $1(1 \%)$ & $3(2,9 \%)$ \\
\hline
\end{tabular}

30 Hubungan Pelajar SMA Dengan Guru Di Kotamadya Bandung 
Edutech, Tahun 13, Vol.1, No.1, Februari 2014

\begin{tabular}{|l|c|c|c|}
\hline Tidak ada upaya & $7(6,9 \%)$ & $5(4,9 \%)$ & $12(11,7 \%)$ \\
\hline Lainnya & - & $1(1 \%)$ & $1(1 \%)$ \\
& & & $102(100 \%)$ \\
\hline Total & $64(62,7 \%)$ & $38(37,3 \%)$ & \\
\hline
\end{tabular}

Sumber: Hasil survei 2012

Keterangan :

$1=$ Upaya

$2=$ Persoalan Sulit Memahami

$3=$ Persoalan Pelajaran Terhambat

$4=$ Jumlah

Berikut ini perbandingan upaya yang dengan guru dan mata pelajaran dengan dilakukan dalam mengatasi persoalan bobot presentase terbesar.

\begin{tabular}{|c|c|}
\hline Upaya : Guru & Upaya : Mata Pelajaran \\
\hline 1. Tidak ada upaya $(44,6 \%)$ & 1. Belajar sendiri $(51 \%)$ \\
\hline 2. Ikut kehendak guru $(21 \%)$ & 2. Ikut les/Bimbingan (21\%) \\
\hline 3. Bantuan orang lain (19\%) & 3. Bertanya pada orang lain $(21 \%)$ \\
\hline 4. Berdialog dengan guru $(7 \%)$ & 4. Taka da upaya (11\%) \\
\hline 5. Usul pada guru (5\%) & 5. Bertanya pada guru (3\%) \\
\hline
\end{tabular}
ini dapat dikatakan upaya memperbaiki

Upaya "pasif" meliputi tidak ada upaya, ikut kehendak guru, dan upaya "mencari jalan sendiri", yaitu meminta bantuan orang lain, ikut les/bimbingan, bukanlah hal yang dapat memperbaiki hubungan dengan guru. Dengan pasif, mereka tetap mempunyai persoalan, hanya diredam ke dalam diri masing-masing. Dengan mencari jalan sendiri, jelas ini makin menjauhi hubungan dengan guru. Hanya sebagian kecil yang mengambil upaya berdialog dan bertanya pada guru, padahal hubungan dengan guru.

Thorndike (1961) dengan teori belajar yang disebut "connected" mengatakan belajar merupakan proses pembentukan koneksi-koneksi antara stimulus dan respons. Teori ini disebut pula "trial and error learning", dimana individu yang belajar melakukan kegiatan melalui proses tersebut dalam memilih respons yang tepat bagi stimulus tertentu. Dalam hal itu objek mencoba berbagai cara bereaksi sehingga menemukan keberhasilan dalam membuat 
Edutech, Tahun 13, Vol.1, No.1, Februari 2014

koneksi suatu reaksi dengan stimulusnya. Ciri belajar dengan "trial and error" yaitu:

1. Ada motif pendorong aktivitas

2. Ada berbagai respons terhadap situasi

3. Ada eliminasi respons-respons yang gagal

4. Ada kemajuan reaksi-reaksi mencapai kemajuan

Apabila dihubungkan dengan apa yang ditemukan pada proses belajar mengajar guru dan pelajar di Kodya Bandung nampaknya hal ini belum/tidak terjadi. Seperti yang dikatakan Hull pada halaman terdahulu, bila melihat respons dari pelajar, yaitu peranan guru dalam memotivasi, atau memberi "prinsip penguat" (reinforcement) bagi $50 \%$ muridnya tidak mencapai sasaran. Namun, bagi pelajar yang tidak mempunyai persoalan dengan guru, hal ini berlaku.

Sebagai ilustrasi, Hamacheek (dalam Soemanto, 1990) mengatakan: apa yang diharapkan dari guru adalah :

1. Guru sebagai fasilitator, dimana dia mengusahakan cara untuk memberikan kemudahan belajar bagi muridnya

2. Guru yang efektif adalah guru yang manusiawi dan dapat bersimpatik pada muridnya. Mereka mempunyai rasa humorm adil, menarik, lebih demokratis daripada otokratis dan mampu berhubungan dengan mudah dan wajar dengan muridnya, baik secara perorangan maupun kelompok.

Sebaliknya guru yang tidak efektif, kurang memiliki rasa humor, tidak sabar, kurang berintegrasi, otoriter dan biasanya kurang peka terhadap kebutuhan-kebutuhan pelajar.

\section{SIMPULAN}

Seperti telah dikemukakan pada sub permasalahan dan judul tulisan, penelitian ini melihat hubungan antara guru dengan murid (pelajar) khususnya di Kota Bandung. Dari uraian hasil temuan dapat disimpulkan :

1. Pada kenyataannya separuh dari pelajar mengalami dan mempunyai masalah dengan guru, berarti hubungan guru-murid kurang harmonis. Hal ini akan mengganggu proses belajar-mengajar, padahal diharapkan dari proses belajar ini akan menghasilkan pelajar-pelajar yang baik dalam prestasi penguasaan materi pelajaran (ilmu).

2. Hampir semua pelajar mengalami dan mempunyai masalah dalam mata pelajaran (94\%). Hal ini harus mendapat perhatian serius, apakah pelajaran itu memang sulit, atau cara menerangkannya kurang jelas, atau muatan beban dan tugas terlalu sarat sehingga pelajar merasa pelajaranpelajaran itu sulit. 
Edutech, Tahun 13, Vol.1, No.1, Februari 2014

3. Tetapi melihat upaya yang dilakukan oleh pelajar, dalam mengatasi kesulitan atau persoalan tersebut, dapat dikatakan positif. Mereka bergulat untuk mengatasinya dengan kadar dan kemampuan yang mereka miliki, sehingga walaupun ada persoalan dengan guru, tidak ada upaya-upaya yang ingin menjaga jarak, menolak atau menghindar dari proses belajar tersebut. Sehingga hubungan dengan guru masih terjaga dengan baik, walaupun persoalanpersoalan itu ada. Masih terlihat rasa hormat dan segan yang tinggi terhadap guru.

\section{DAFTAR PUSTAKA}

Biro Pusat Statistik. 2011. Statistik Jawa Barat. Jakarta

Gagne, Robert M. 1965. The Condition of Learning. Second Edition, Halt, Rinehart and Winston, Inc.

Hanim, Masayu. S \& Bashori Imron, 1993.
Purwanto, Ngalim M. 1993. Psikologi Pendidikan. Bandung : Remaja Rosdakarya

Pokasi, Soepartinah. 1985. Anak dan Perkembangahnya. Jakarta : PT. Gramedia

Rakhmat, Jalaluddin. 1989. Psikologi Komunikasi. Bandung : Remaja Karya

Rasyad Amminuddin. 1990. Sikap Penampilan Profesi Guru (Makalah Seminar Profesionalisme Guru). Jakarta : Yayasan Harapan Ibu

Soemanto, Wasto. 1990. Sosiologi Pendidikan. Jakarta : Rineka Ria

Suryabrata, Sumadi. 1993. Sosiologi Pendidikan. Jakarta : R. G. Persada Thorndike, R.L. Hagen, E.P. 1961. Measurement and Evaluation in Psychology and Education. New York : John Wiley \& Sons.

Vebriarta, St. 1990. Sosiologi Pendidikan. Yogyakarta : Andi Offset

Profil Orang Muda dan

Transformasi Pola Komunikasi dalam Proses Industrialisasi, Kasus Pelajar di Kotamadya Surabaya. Jakarta : PMB-LIPI

Mustakim \& Abdul Wahib, 1991. Psikologi Pendidikan. Jakarta : Rineka Ria 